\title{
Flint artefacts from Rivne (Ukraine) in the collection of the District Museum in Toruń
}

\section{Beata Bielińska-Majewska}

\begin{abstract}
The aim of this publication is to present and illustrate selected bifacial products from amongst the flint artefacts from Rivne (Ukraine) that are a part of the collection of the Torun District Museum's Archaeological Department. There is no data on their exact origin or the circumstances in which they were collected, thus analysing them we have to be very cautious. By means of typological and comparative classification we can define them as Late Neolithic to Bronze Age.
\end{abstract}

Kivonat

\section{Kovakő eszközök Rivnéből a Toruńi Körzeti Múzeum gyűjteményében}

A tanulmány néhány kétoldali megmunkálású kovaeszközt mutat be, melyek Rivnéből (Ukrajna) származnak, és jelenleg a Toruńi Körzeti Múzeum Régészeti Osztálya őrzi őket. A darabok eredet és fellelésük pontos körülményei ismeretlenek, ezért az analízis rendkívül óvatos. Összehasonlító tipológiai vizsgálat alapján a kövek késő neolitikus - korai bronzkori darabok lehetnek.

\section{Keywords}

Kulcsszavak
Volhynian flint, bifacial products, Rivne (Ukraine), museum collections

Volhíniai kova, kétoldali megmunkálású darabok, Rivne (Ukrajna), múzeumi gyújtemény

Author / Szerző

Department of Archaeology, District Museum in Toruń, ul. Św Jakuba 20a, 87-100 Toruń (Poland)

E-mail: bmmajewscy@gmail.com

Cite as / Hivatkozás Bielińska-Majewska, B. (2015) Flint artefacts from Rivne (Ukraine) in the collection of the District Museum in Toruń. Litikum 3: 39-45. https://doi.org/10.23898/litikuma0011

Article history /

Kézirat történet

Copyright / Jogok

Received // Érkezés: 2015. 10 . 18. Accepted // Elfogadás: 2015. 12. 04. Published // Közzététel: 2016. 02. 20.

(c) 2015 Bielińska-Majewska. This is an open-access article distributed under the terms of the Creative Commons Attribution License, which permits unrestricted use, distribution, and reproduction in any medium, provided the original author and source are credited. // Ez egy nyílt hozzáférésű publikáció, amit a Creative Commons 4.0 licensze véd. A termék szabadon használható, terjeszthető és sokszorosítható az eredeti szerző és forrás megjelölése mellett.

\section{Introduction}

District Museum in Toruń has a rich collection of archaeological artefacts accumulated over a long period of time and in various circumstances, such as: products, assemblies, and inventories dating from the Palaeolithic through to modern times. These artefacts come from regular and rescue excavations, as well as surface surveys. Some of the items have been obtained for the museum as gifts from private individuals. The aim of this publication is to present and illustrate selected bifacial products from amongst the flint artefacts that came to the museum in 1949 as a gift from Mikołaj Karpow-Lipski.

\section{Data}

The presented artefacts are stored in the collection of the Torun District Museum's Archaeological Department under the inventory number MT/A/191. In the inventory books and catalogue cards these are described as coming from Rivne (Równe) in Ukraine (Fig. 1).

As was pre-determined Mikołaj Karpow-Lipski may be the person about whom Tomasz Bojarczuk writes in his article (Bojarczuk 2010). It should be mentioned that Karpow-Lipski (1896-1981) traveled extensively. Among other places he was in Zdolbuniv, and at the beginning of the World War I he moved with his family to Kostopil in Volhynia, during 
World War II he was employed at the experimental station of the German department of medicinal herbs in Rivne (Bojarczuk 2010: 81). As in the museum archives there is no information on the exact location or the specific circumstances of the method of obtaining flint products, we can only assume that the materials were collected by KarpowLipski during hikes in and around Rivne.

\section{Discussion}

The collection transferred to the museum comprises of 24 flint products, which were made from a uniform flint type of good quality - Volhynian flint. This kind of flint occurs, inter alia in western Ukraine, north-western part of the Volhynia plane and in Volhynian Polesie (Taras 1997). The publication characterizes 14 flint forms developed with bifacial retouch. Other products which are excluded from the analysis are mainly debris, cores, flakes and blades.

On the basis of the initial macroscopic materials analysis, it seems that these products could originate from one site. They are characterized by a similar technique and style of make. The general condition of the artefacts is good. Among the presented products there are the following forms: four axes (including one preform), five tool fragments (including likely fragments of the points and handles), two sickleshaped knifes, one probable cutting tool preform and two unspecified products. The products are shown in the figures (Fig. 2-5).

Based on preliminary characteristics we can say that the surfaces of the axes are developed by large planar retouch, and the edges are finished with fine retouch. These tools have straight or slightly curved sides. On one of the axes there are fragmentary remains of cortex (Fig. 2.1). Only one of the axes is smaller in size compared with the others and is covered with a patina (Fig. 2.2). As mentioned earlier, one of the specimens is probably an axe preform (Fig. 2.4). The first of the two bifacial knife specimens is made by means of a careful retouch of the surface (Fig. 3.1), while the second is developed carelessly (Fig. 3.2). Amongst the tools there was also a point preform or a point with a marked handle (Fig. 3.3). Its lower (ventral) side is covered with surface retouch, while the upper (dorsal) side shows fragmentary remains of cortex. Portions of the edges are developed with nearedge retouch. Among the tool fragments there are: a point fragment (of a very precise surface retouch) (Fig. 4.1), two probable handles (Fig. 4.2-3) and two tool fragments (one a probable axe fragment, Fig. 4.4). In the analyzed material there were also two unspecified products (Fig. 5.1-2).

In thematic literature the selected tools, mainly points and knives occur under various names. Bifacial projectile points are divided into several types and subtypes, such as: daggers, points, spearheads and bifacial projectile points (Libera 2001). They are made of flat or fragmented natural concretions, flakes or blades. Their surfaces are formed with flat two-sided regular retouch. Similarly, the bifacial knives in Polish literature also carry various names. They are called i.e. sickles or sickle-shaped knives (Libera 2001). These were made of flat nodules massive blades and flakes. Their surfaces are formed flat as described above and evened out along the edges, occasionally with the use of denticulated retouch. It should be mentioned that in the Early Bronze Age prepared-core technique was used. It allowed production of specialised tools (of high quality raw material), such as: sickles, axes, etc.

\section{Conclusions}

Concluding it should be noted that the presented flint artefacts are loose finds lacking stratigraphic and cultural context, which makes practically impossible to define their chronological and cultural affiliation. In addition, the already mentioned lack of detailed historical data on their acquisition and circumstances of the discovery leads to a very careful typological and comparative classification. Nonetheless, the analyzed materials were defined as probably Late Neolithic to Bronze Age.

Presented flint products have not been previously published. These materials should be treated as archival sources that complement our knowledge on obtaining artefacts to museums in the early twentieth century. In addition, they complement our data on this category of artefacts stored in museum collections.

\section{Acknowledgements}

The author would like to thanks M.A. Maciej Majewski for the English translation and arrangement of figures and M.A. Krzysztof Deczyński for taking photographs of the artefacts.

\section{References}

Bojarczuk T. 2010. Mikołaj Karpow-Lipski (1896-1981), ogrodnikhodowca roślin. Rocznik Polskiego Towarzystwa Dendrologicznego 58: 79-82.

Libera J. 2001. Krzemienne formy bifacjalne na terenach Polski $i$ zachodniej Ukrainy (od środkowego neolitu do wczesnej epoki żelaza). Lublin: Wydawnictwo Uniwersytetu Marii Curie-Skłodowskiej.

Taras H. 1997. Krzemieniarstwo kultury trzcinieckiej na wyżynach Wschodniowielkopolskiej i Zachodniowołyńskiej oraz na zachodnim Podlasiu. In: J. Lech and D. Piotrkowska (eds.), Z badań nad krzemieniarstwem epoki brazu i wczesnej epoki żelaza. Warszawa: Wydawnictwa Naukowe PWN, 163-183.

\section{SKAM 2014 Article}

This study was presented at the 11th SKAM Lithic Workshop: the multifaceted biface - Bifacial technology in Prehistory. 20th-22nd of October, 2014, Miskolc, Hungary. The conference papers are published in the Litikum Journal volumes as special contributions. Informations about the conference are available on the SKAM 2014 website: http:// skam.pannontenger.hu 


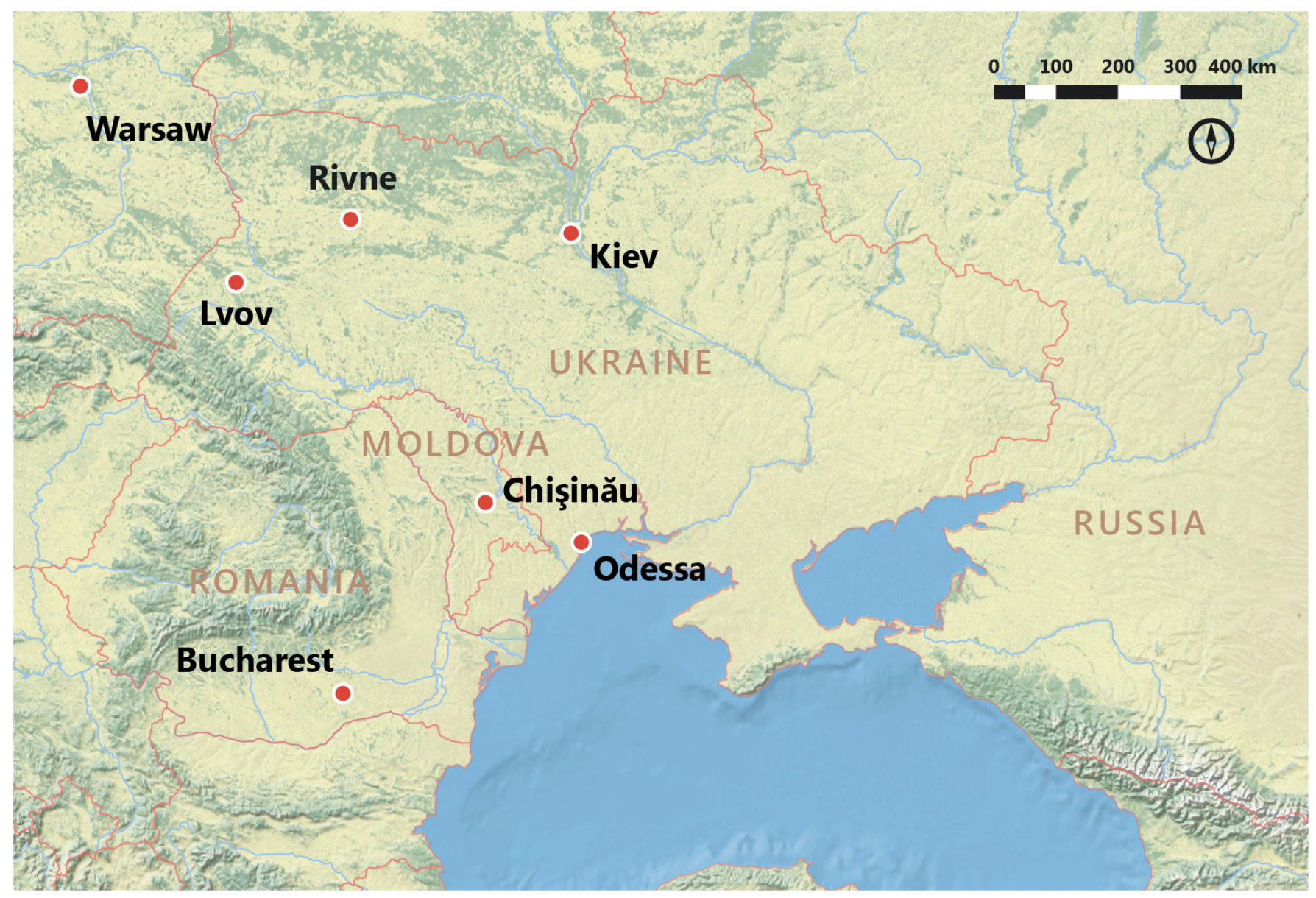

Figure 1. Location of Rivne (Równe), Ukraine. // 1. ábra. Rivne (Równe) földrajzi helyzete Ukrajnában. 

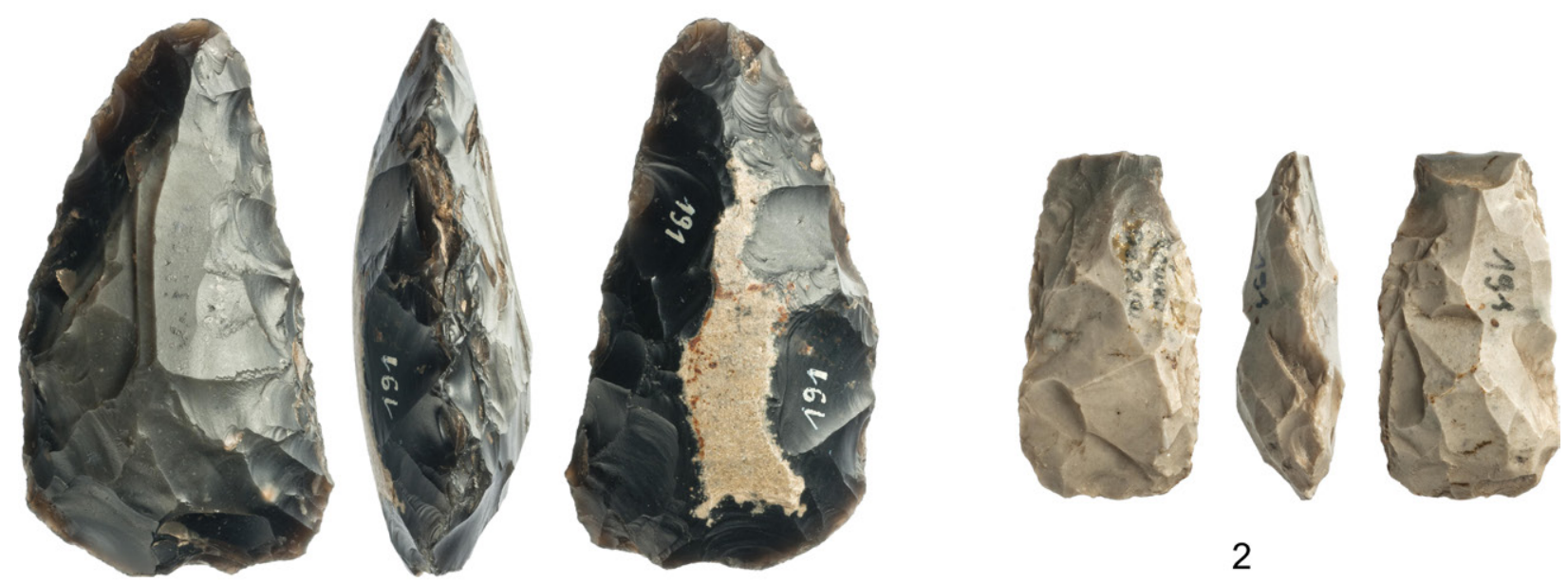

1
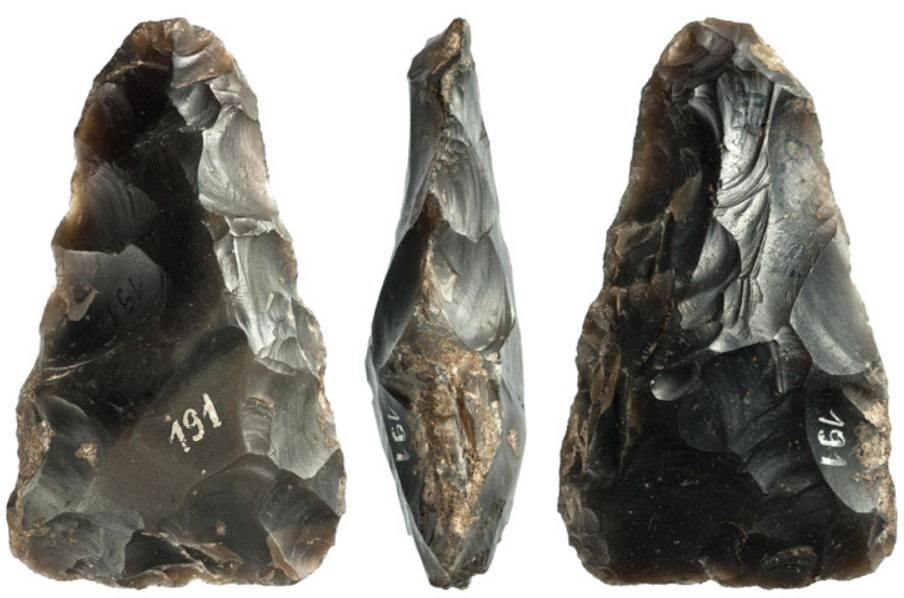

3

2
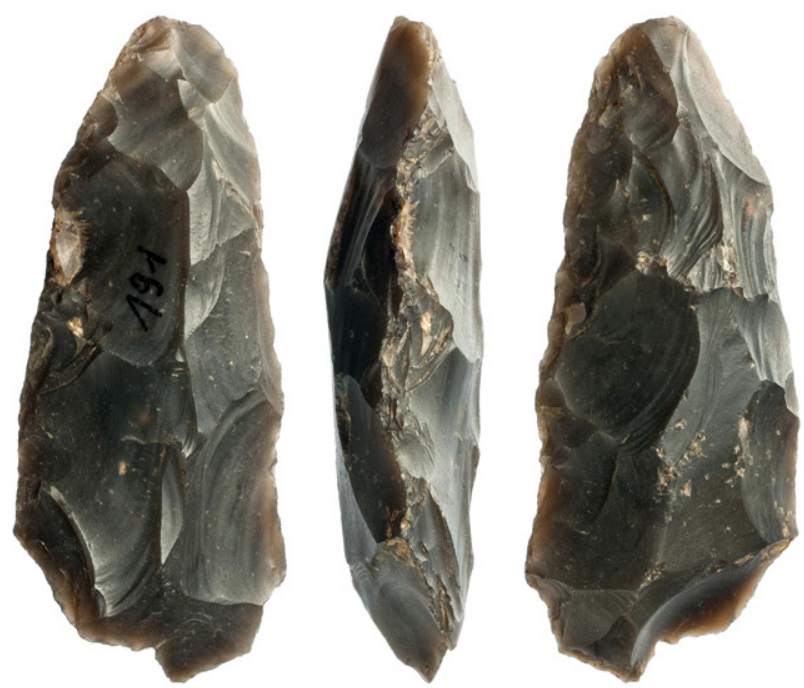

4

0

Figure 2. Rivne (Równe), Ukraine. Flint artefacts. 1-3: axes; 4: axe preform. // 2. ábra. Rivne (Równe), Ukrajna, kova eszközök. 1-3: balták; 4: félkész balta. 

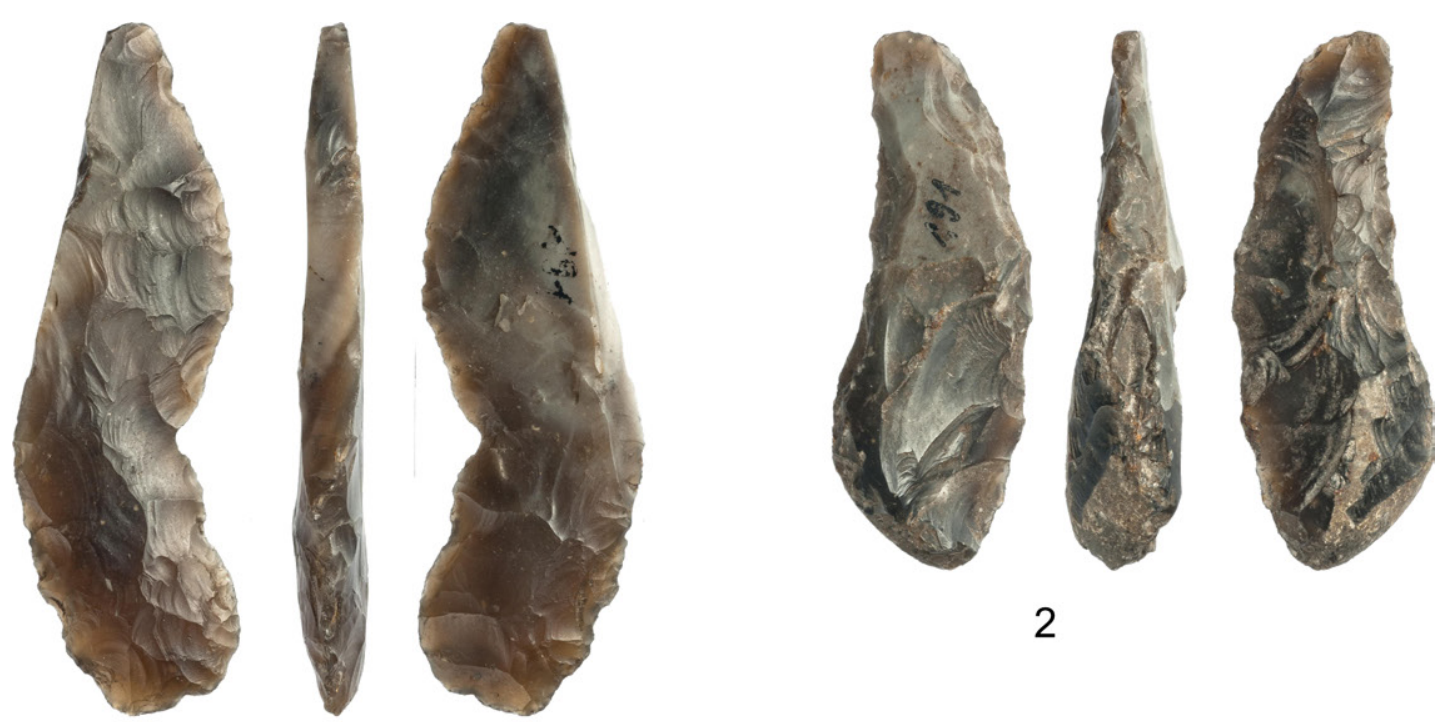

2

1
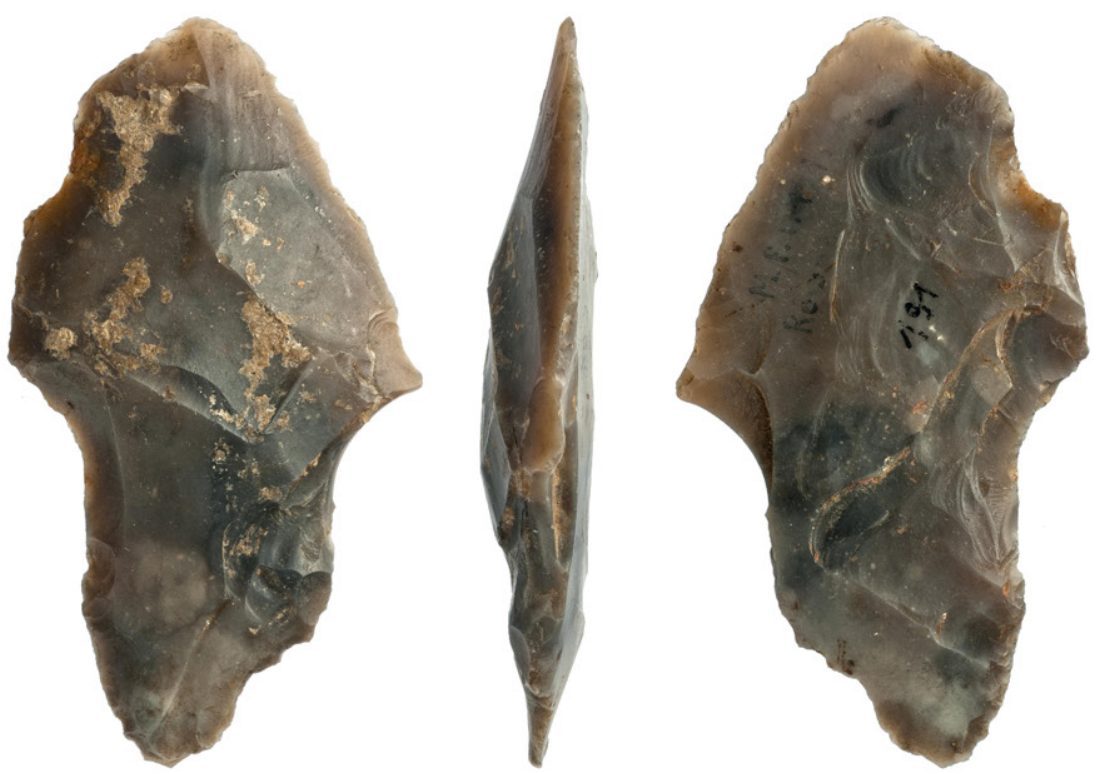

3

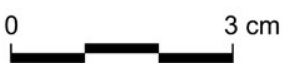

Figure 3. Rivne (Równe), Ukraine. Flint artefacts. 1: sickle-shaped knife; 2: sickle-shaped knife preform (?); 3: point preform (?). // 3. ábra. Rivne (Równe), Ukrajna, kova eszközök. 1: sarló alakú kés; 2: félkész sarló alakú kés (?); 3: félkész hegy (?). 

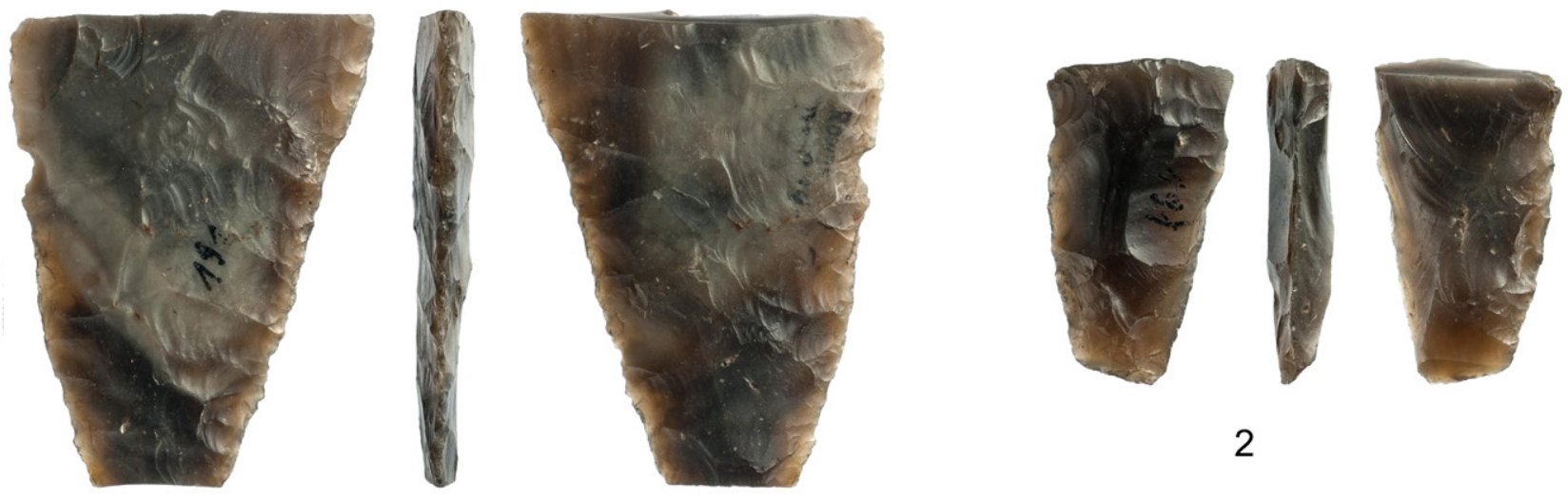

2

1
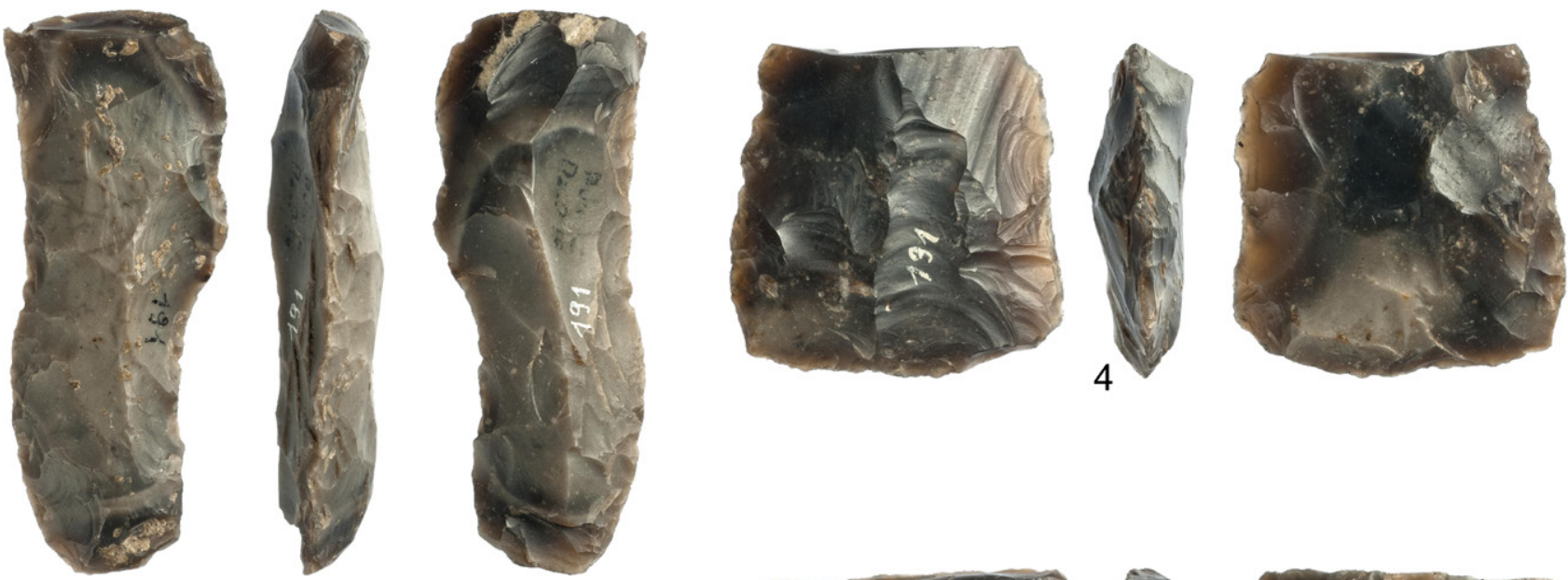

3
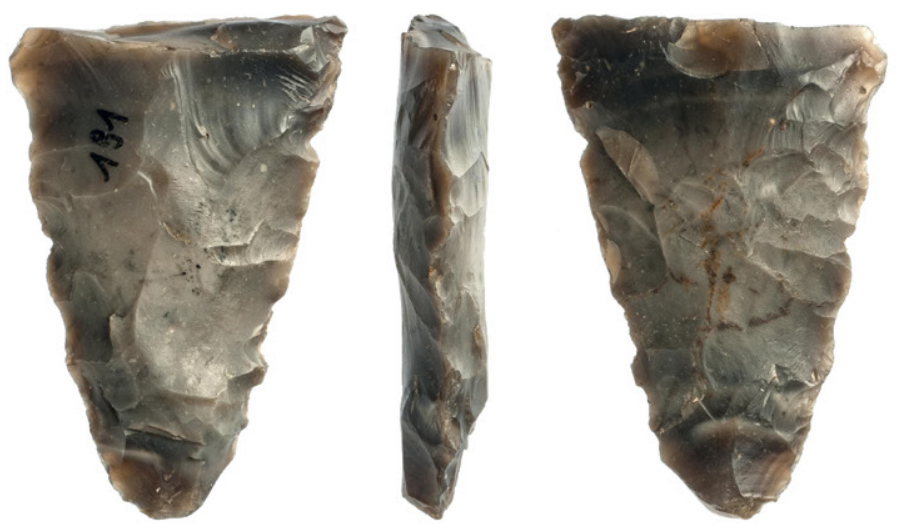

5

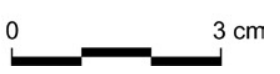

Figure 4. Rivne (Równe), Ukraine. Flint artefacts. 1: point fragment; 2-3, 5: tool fragments; 4: axe (?) fragment. // 4. ábra. Rivne (Równe), Ukrajna, kova eszközök. 1: hegy töredéke; 2-3, 5: töredékes eszközök; 4: balta töredéke (?). 

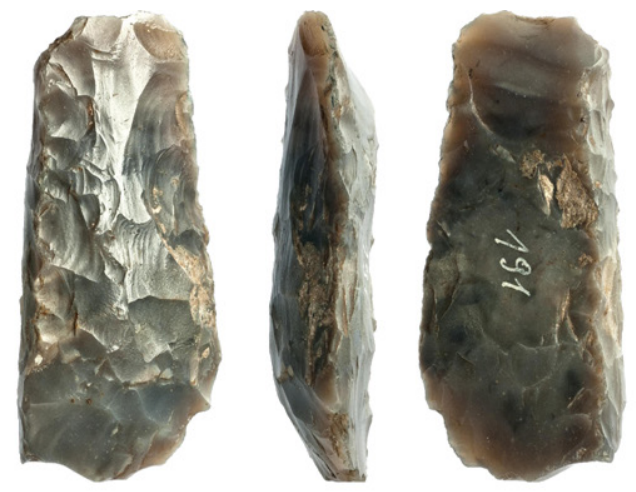

1
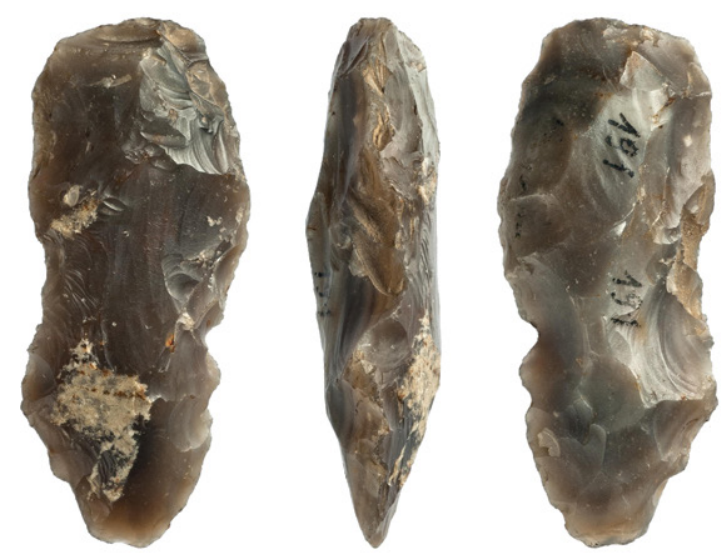

2

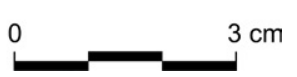

Figure 5. Rivne (Równe), Ukraine. Flint artefacts. 1-2: tools. // 5. ábra. Rivne (Równe), Ukrajna, kova eszközök. 1-2: eszközök. 